\title{
Densities and Derived Thermodynamic Properties of Imidazolium-, Pyridinium-, Pyrrolidinium-, and Piperidinium-Based Ionic Liquids
}

\author{
Ramesh L. Gardas, ${ }^{\ddagger}$ Henrique F. Costa, ${ }^{\S}$ Mara G. Freire, ${ }^{\ddagger}$ Pedro J. Carvalho,${ }^{\ddagger}$ Isabel M. Marrucho,${ }^{\ddagger}$ \\ Isabel M. A. Fonseca, ${ }^{\S}$ Abel G. M. Ferreira, ${ }^{*, \$}$ and João A. P. Coutinho \\ CICECO, Departamento de Química, Universidade de Aveiro, 3810-193 Aveiro, Portugal, and Departamento de Engenharia \\ Química, Faculdade de Ciências a Tecnologia, Universidade de Coimbra, Polo II, Pinhal de Marrocos, 3030-290 Coimbra, Portugal
}

\begin{abstract}
In the present work, experimental density measurements are reported along with the derived thermodynamic properties, such as the isothermal compressibility $\left(\kappa_{T}\right)$, the isobaric expansivity $\left(\alpha_{p}\right)$, and the thermal pressure coefficient $\left(\gamma_{v}\right)$ for imidazolium-, pyridinium-, pyrrolidinium-, and piperidinium-based ionic liquids (ILs), namely, 1-ethyl-3-methylimidazolium trifluoromethanesulfonate $\left[\mathrm{C}_{2} \mathrm{mim}\right]\left[\mathrm{CF}_{3} \mathrm{SO}_{3}\right], 3$-methyl-1-propylpyridinium bis(trifluoromethylsulfonyl)imide $\left[\mathrm{C}_{3} \mathrm{mpy}\right]\left[\mathrm{NTf}_{2}\right]$, 1-methyl-1-propylpyrrolidinium bis(trifluoromethylsulfonyl)imide $\left[\mathrm{C}_{3}\right.$ mpyr $]\left[\mathrm{NTf}_{2}\right]$, 1-butyl-1-methylpyrrolidinium bis(trifluoromethylsulfonyl)imide $\left[\mathrm{C}_{4}\right.$ mpyr $]\left[\mathrm{NTf}_{2}\right]$, and 1-methyl-1-propylpiperidinium bis(trifluoromethylsulfonyl)imide $\left[\mathrm{C}_{3}\right.$ mpip $]\left[\mathrm{NTf}_{2}\right]$ in the pressure $(0.10<P / \mathrm{MPa}<35.00)$ and temperature $(293.15<T / \mathrm{K}<393.15)$ domains. These ILs were chosen to provide an understanding of the influence of the cation and anion on the properties under study. Experimental densities are correlated with the Tait equation with an average absolute relative deviation (AARD) better than $0.02 \%$. It is shown that experimental densities are in good agreement with the densities obtained by the predictive method previously proposed by us.
\end{abstract}

\section{Introduction}

The widespread use of volatile organic compounds (VOCs) in many industrial chemical processes is an issue of great environmental concern. VOCs released into the atmosphere by industrial processes and products ${ }^{1}$ contribute to climatic changes, air pollution, and human health-related issues. ${ }^{2}$ Therefore, the search for possible alternative compounds becomes essential due to the growing interest in green technologies. For the past few years, ionic liquids (ILs) have been considered one of the most promising alternatives to VOCs.

The research areas on ILs are growing very rapidly, and the potential applications of ILs are numerous. Their unique properties make them useful in important areas such as solvents for chemical synthesis and catalysis; in liquid-liquid extractions; in gas-liquid absorption; in liquid membrane separations; as electrolytes in electrochemistry, in fuel and solar cells; in nanomaterial technologies; in the preparation of polymer-gel catalytic membranes; as stationary phases for chromatography; as matrices for mass spectrometry; as supports for the immobilization of enzymes; as liquid crystals; as heat transfer fluids; as azeotrope-breaking fluids, lubricants, and plasticizers; as anticorrosion coatings, electropolishing agents, antimicrobial agents; and in the generation of highconductivity materials. ${ }^{3-16}$

Although much work has been devoted to the wide range of applications of ILs, the basic understanding and study of their structure-property relationships has not been made extensively. To better understand the nature of ionic liquids and rationally expand their applications, knowledge of their physical properties is required. The design of industrial processes and new products based on ILs can only be achieved when their thermophysical properties, such as viscosity, density, and interfacial tension,

\footnotetext{
* To whom correspondence should be addressed. E-mail: abel@eq.uc.pt. $*$ Universidade de Aveiro.

\& Universidade de Coimbra.
}

are adequately characterized. The IUPAC Ionic Liquid database (ILThermo) provides up-to-date information on thermophysical properties of ILs and their mixtures, with more than 40000 total data points from 231 publications. ${ }^{17}$ During the past few years, investigations on thermophysical and thermodynamic properties of pure ILs have increased; ${ }^{18-35}$ however, they are by no means exhaustive, and it is necessary to accumulate a sufficiently large data bank not only for process and product design but also for the development of correlations for these properties.

This paper is a continuation of previous works ${ }^{36,37}$ on highpressure densities and derived thermodynamic properties of ILs. In this work, the experimental measurements of the pressure $(0.10<P / \mathrm{MPa}<35.00)$ and temperature $(293.15<T / \mathrm{K}<$ 393.15) dependence of the density of imidazolium-, pyridinium-, pyrrolidinium-, and piperidinium-based ionic liquids (ILs), namely, 1-ethyl-3-methylimidazolium trifluoromethanesulfonate $\left[\mathrm{C}_{2}\right.$ mim $]\left[\mathrm{CF}_{3} \mathrm{SO}_{3}\right]$, 3-methyl-1-propylpyridinium bis(trifluoromethylsulfonyl)imide $\left[\mathrm{C}_{3} \mathrm{mpy}\right]\left[\mathrm{NTf}_{2}\right]$, 1-methyl-1-propylpyrrolidinium bis(trifluoromethylsulfonyl)imide $\left[\mathrm{C}_{3}\right.$ mpyr $]\left[\mathrm{NTf}_{2}\right]$, 1-butyl-1-methylpyrrolidinium bis(trifluoromethylsulfonyl)imide $\left[\mathrm{C}_{4} \mathrm{mpyr}\right]\left[\mathrm{NTf}_{2}\right]$, and 1-methyl-1-propylpiperidinium bis(trifluoromethylsulfonyl)imide $\left[\mathrm{C}_{3}\right.$ mpip] $\left[\mathrm{NTf}_{2}\right]$ are presented. The experimental densities were correlated with the Tait equation, and the estimation method proposed by Gardas and Coutinho ${ }^{39}$ was applied. Derived thermodynamic properties, such as the isothermal compressibility $\left(\kappa_{T}\right)$, the isobaric expansivity $\left(\alpha_{p}\right)$, and the thermal pressure coefficient $\left(\gamma_{v}\right)$ are reported as Supporting Information.

The objective of this work is to contribute to the data bank of thermodynamic properties of pure ILs and to investigate the relationship between densities and the ionic structures, to establish principles for the molecular design of ILs. For that purpose, the $\left[\mathrm{NTf}_{2}\right]$ anion was studied in combination with four cations, $\left[\mathrm{C}_{3} \mathrm{mpy}\right],\left[\mathrm{C}_{3} \mathrm{mpyr}\right]\left[\mathrm{C}_{4} \mathrm{mpyr}\right]$, and $\left[\mathrm{C}_{3} \mathrm{mpip}\right]$, to con- 
Table 1. Experimental Density, $\rho$, Data for $\left[\mathrm{C}_{2} \mathrm{mim}\right]\left[\mathrm{CF}_{3} \mathrm{SO}_{3}\right]$, $\left[\mathrm{C}_{3}\right.$ mpy] $\left[\mathrm{NTf}_{2}\right]$, and $\left[\mathrm{C}_{3}\right.$ mpip] $\left[\mathrm{NTf}_{2}\right]$ as a Function of Temperature and Pressure

\begin{tabular}{|c|c|c|c|c|c|c|c|}
\hline \multirow[b]{2}{*}{$p / \mathrm{MPa}$} & \multicolumn{7}{|c|}{$\rho / \mathrm{kg} \cdot \mathrm{m}^{-3}$ at $T / \mathrm{K}$} \\
\hline & 293.15 & 303.15 & 313.15 & 323.15 & 333.15 & 353.15 & 393.15 \\
\hline \multicolumn{8}{|c|}{$\left[\mathrm{C}_{2} \operatorname{mim}\right]\left[\mathrm{CF}_{3} \mathrm{SO}_{3}\right]$} \\
\hline 0.10 & 1379.6 & 1370.2 & 1361.1 & 1352.0 & 1342.8 & 1325.3 & 1291.1 \\
\hline 1.00 & 1380.0 & 1370.7 & 1361.6 & 1352.5 & 1343.3 & 1325.9 & 1291.7 \\
\hline 2.00 & 1380.6 & 1371.5 & 1362.2 & 1353.2 & 1344.0 & 1326.6 & 1292.4 \\
\hline 3.00 & 1381.1 & 1372.1 & 1362.9 & 1353.8 & 1344.6 & 1327.2 & 1293.2 \\
\hline 4.00 & 1381.8 & 1372.7 & 1363.5 & 1354.4 & 1345.3 & 1327.9 & 1293.9 \\
\hline 5.00 & 1382.5 & 1373.2 & 1364.1 & & & & 1294.5 \\
\hline 7.50 & 1383.9 & 1374.6 & 1365.7 & 1356.7 & 1347 & 1330.3 & 129 \\
\hline 10.00 & 1385.4 & 1376.1 & 1367.3 & 1358.2 & 1349.2 & 1332.0 & 1298.1 \\
\hline 15.00 & 1388.2 & 1379.0 & 1370.2 & 1361.2 & 1352.3 & 1335.3 & 1302.0 \\
\hline 20.00 & 1391.0 & 1381.9 & 1373.1 & 1364.2 & 1355.4 & 1338.5 & 1305.2 \\
\hline 25.00 & 1393.7 & 1384.7 & & & & & \\
\hline 30.00 & 1396.4 & 1387.5 & 1378 & & & & \\
\hline 35.00 & 1399.1 & 1390.2 & 1381.6 & 1372.9 & 1364.3 & 1347.8 & 1315.3 \\
\hline \multicolumn{8}{|c|}{$\left[\mathrm{C}_{3} \mathrm{mpy}\right]\left[\mathrm{NTf}_{2}\right]$} \\
\hline 0.10 & 1454.9 & 1444.4 & & & 1413.6 & 1393.7 & 1354.8 \\
\hline 1.00 & 1455.6 & 1445.3 & 143 & & 141 & & \\
\hline 2.00 & 1456.4 & 1446.1 & 1435.6 & 1425.3 & 1415.3 & 1395.5 & 1356.9 \\
\hline 3.00 & 1457.1 & 1446.8 & 1436.4 & 1426.1 & 1416.1 & 1396.4 & 1357.9 \\
\hline 4.00 & 1457.9 & 1447.6 & 1437.3 & 1427.0 & 1417.0 & 1397.4 & 1359.0 \\
\hline 5.00 & 1458.7 & 1448.4 & & & 141 & & \\
\hline 7.50 & 1460.5 & 145 & & 29.9 & 141 & 1400.2 & 136 \\
\hline 10.00 & 1462.4 & 145 & & & & & \\
\hline 15.00 & 1466.1 & 1455.9 & 1445.7 & 1435.7 & 1425.9 & 1406.8 & 1369.7 \\
\hline 20.00 & 1469.6 & 1459.6 & 1449.5 & 1439.5 & 1429.9 & 1411.0 & 1374.3 \\
\hline 25.00 & 1473.1 & 1463.1 & 1453.1 & 1443.3 & 1433.7 & 1415.1 & 1378.8 \\
\hline 30.00 & 1476.5 & 1466.6 & 1456.7 & 1446.9 & 1437.4 & 1419.0 & 138 \\
\hline 35.00 & 1479.8 & 1470.0 & 1460.3 & 1450.5 & 1441.1 & 1422.9 & 1387.5 \\
\hline \multicolumn{8}{|c|}{$\left[\mathrm{C}_{3} \mathrm{mpip}\right]\left[\mathrm{NTf}_{2}\right]$} \\
\hline 0.10 & 1416.9 & 1407.2 & 1397.4 & 1387.6 & 1377.0 & 1358.5 & 1322.3 \\
\hline 1.00 & 1417.6 & 1407.8 & 1398.1 & 1388.3 & 1377.8 & 1359.3 & 1323.2 \\
\hline 2.00 & 1418.3 & 1408.6 & & 1389.1 & 1378.6 & 1360.2 & 1324.3 \\
\hline 3.00 & 1419.0 & 1409.3 & 1399.5 & 1389.9 & 1379.3 & 1361.1 & 1325.3 \\
\hline 4.00 & 1419.6 & 1410.0 & 1400.2 & 1390.6 & 1380.1 & 1361.9 & 1326.2 \\
\hline 5.00 & 1420.3 & 1410.7 & 1401.0 & 1391.4 & 1380.9 & 1362.8 & 1327.3 \\
\hline 7.50 & 1422.0 & 1412.5 & 1402.8 & 1393.2 & 1382.8 & 1364.7 & 1329.7 \\
\hline 10.00 & 1423.8 & 1414.3 & 1404.7 & 1395.1 & 1384.8 & 1366.7 & 1331.8 \\
\hline 15.00 & 1427.1 & 1417.7 & 1408.2 & 1398.7 & 1388.5 & 1370.7 & 1336.3 \\
\hline 20.00 & 1430.4 & 1421.1 & 1411.7 & 1401.9 & 1392.3 & 1374.7 & 1340.7 \\
\hline 25.00 & 1433.7 & 1424.4 & 1415.1 & 1405.0 & 1396.0 & 1378.4 & 1344.8 \\
\hline 30.00 & 1436.8 & 1427.6 & 1418.4 & 1408.6 & 1399.5 & 1382.1 & 1348.9 \\
\hline 35.00 & 1439.9 & 1430.7 & 1421.7 & 1412.1 & 1403.0 & 1385.7 & 1353.0 \\
\hline
\end{tabular}

clude about the cation effect and also to study the effect of alkyl chain length on the pyrrolidinium ring on the density and derived properties. The effect of alkyl chain length on the imidazoliumbased ILs, having the $\left[\mathrm{CF}_{3} \mathrm{SO}_{3}\right]$ anion, on the density and derived properties has been studied. This study complements our previously published data ${ }^{36}$ for 1-butyl-3-methylimidazolium trifluoromethanesulfonate $\left[\mathrm{C}_{4} \mathrm{mim}\right]\left[\mathrm{CF}_{3} \mathrm{SO}_{3}\right]$. To the best of our knowledge, this is also the first description of densities and derived properties of $\left[\mathrm{C}_{3} \mathrm{mpy}\right]\left[\mathrm{NTf}_{2}\right]$ and $\left[\mathrm{C}_{3} \mathrm{mpip}\right]\left[\mathrm{NTf}_{2}\right]$ ILs.

\section{Experimental Section}

Materials. Experimental densities were measured for imidazolium-, pyridinium-, pyrrolidinium-, and piperidinium-based ILs, namely, $\left[\mathrm{C}_{2} \operatorname{mim}\right]\left[\mathrm{CF}_{3} \mathrm{SO}_{3}\right], \quad\left[\mathrm{C}_{3} \mathrm{mpy}\right]\left[\mathrm{NTf}_{2}\right], \quad\left[\mathrm{C}_{3} \mathrm{mpyr}\right]\left[\mathrm{NTf}_{2}\right]$, $\left[\mathrm{C}_{4} \mathrm{mpyr}\right]\left[\mathrm{NTf}_{2}\right]$, and $\left[\mathrm{C}_{3} \mathrm{mpip}\right]\left[\mathrm{NTf}_{2}\right]$. The $\left[\mathrm{C}_{2} \mathrm{mim}\right]\left[\mathrm{CF}_{3} \mathrm{SO}_{3}\right]$ was acquired at IoLiTec with mass fraction purities $>99 \%$ and halogen free since it was produced directly from ethylimidazole and methyltriflate. $\left[\mathrm{C}_{3} \mathrm{mpy}\right]\left[\mathrm{NTf}_{2}\right],\left[\mathrm{C}_{3} \mathrm{mpyr}\right]\left[\mathrm{NTf}_{2}\right],\left[\mathrm{C}_{4} \mathrm{mpyr}\right]\left[\mathrm{NTf}_{2}\right]$, and $\left[\mathrm{C}_{3}\right.$ mpip $]\left[\mathrm{NTf}_{2}\right]$ were acquired from IoLiTec with mass fraction purities $>99 \%$ and a bromide impurity mass fraction < $10^{-4}$.

To reduce the water content and volatile compounds to negligible values, a vacuum $(0.1 \mathrm{~Pa})$ at moderate temperature
(353 K) for at least $48 \mathrm{~h}$ was applied to all the IL samples prior to their use. After this procedure, we checked the purity of each IL by ${ }^{1} \mathrm{H},{ }^{13} \mathrm{C}$, and ${ }^{19} \mathrm{~F}$ NMR, and the water content in the ILs was determined, with a Metrohm 831 Karl Fischer coulometer indicating very low levels of water mass fraction content, as (21, $48,26,21$, and 22$) \cdot 10^{-6}$ for $\left[\mathrm{C}_{2} \mathrm{mim}\right]\left[\mathrm{CF}_{3} \mathrm{SO}_{3}\right],\left[\mathrm{C}_{3} \mathrm{mpy}\right]\left[\mathrm{NTf}_{2}\right]$, $\left[\mathrm{C}_{3} \mathrm{mpyr}\right]\left[\mathrm{NTf}_{2}\right],\left[\mathrm{C}_{4} \mathrm{mpyr}\right]\left[\mathrm{NTf}_{2}\right]$, and $\left[\mathrm{C}_{3} \mathrm{mpip}\right]\left[\mathrm{NTf}_{2}\right]$, respectively. The analyte used for the coulometric Karl Fischer titration was Hydranal-Coulomat AG from Riedel-de Haën.

Experimental Procedure. Experimental densities were measured using an Anton Paar DMA 60 digital vibrating tube densimeter, with a DMA 512P measuring cell in the temperature range (293.15 to 393.15$) \mathrm{K}$ and pressure range ( 0.10 to 35.00$) \mathrm{MPa}$. The temperature in the vibrating tube cell was measured with a platinum resistance probe which has a temperature uncertainty of $\pm 0.01 \mathrm{~K}$ coupled with a GW Instek Dual Display Digital Multimeter GDM-845. A Julabo P-5 thermostatic bath with silicone oil as circulating fluid was used in the thermostat circuit of the measuring cell which was held constant to $\pm 0.01 \mathrm{~K}$.

The required pressure was generated and controlled with a Pressure Generator model 50-6-15, High Pressure Equipment Co., using acetone as the hydraulic fluid. The diameter of the metallic tube is $1.59 \cdot 10^{-3} \mathrm{~m}$, and the buffer is more than $1 \mathrm{~m}$ in length which guarantees the inexistence of diffusion of the hydraulic liquid in the liquid contained in the cell of the densimeter. Pressures were measured with a pressure transducer (Wika Transmitter S-10, WIKA Alexander Wiegand GmbH \& Co.) with a maximum uncertainty of $\pm 0.03 \mathrm{MPa}$. An NI PCI6220 data acquisition board (DAQ) from National Instruments (NI) was used for the real-time registration of values of period, temperature, and pressure. For this task, a Labview application was developed. Modules of temperature (NI SCC-FT01) and pressure (NI SCC-CI20) were installed into an NI SC-2345 carrier and connected to the DAQ board.

The calibration of the vibrating tube densimeter was described in a previous work of Gardas et al. ${ }^{40}$ The equation proposed by Niesen $^{41}$ which has a solid theoretical basis as discussed by Holcom and Outcalt ${ }^{42}$ was used for that purpose. The standard deviation of the fitting is in the order of $\pm 1 \mathrm{~kg} \cdot \mathrm{m}^{-3}$. The average absolute relative deviation, AARD, from the experimental data to the fitting is $0.02 \%$ for all the ILs studied.

The influence of the viscosity on the densities was evaluated. To check the effect of viscosity in the density, a viscosity correction for compounds with viscosities $<100 \mathrm{mPa} \cdot \mathrm{s}$ was applied with the equation proposed for the density uncertainty of an Anton Paar DMA 512 densimeter. ${ }^{43}$ For compounds with viscosities higher than $400 \mathrm{mPa} \cdot \mathrm{s}$, the correction factor becomes constant ${ }^{44}$ and equal to $0.5 \mathrm{~kg} \cdot \mathrm{m}^{-3}$, and between (100 and 400) $\mathrm{mPa} \cdot \mathrm{s}$, the viscosity correction follows an intermediate behavior. For example, the available viscosity data for $\left[\mathrm{C}_{2} \mathrm{mim}\right]\left[\mathrm{CF}_{3} \mathrm{SO}_{3}\right]^{45}$ and $\left[\mathrm{C}_{4} \mathrm{mpyr}\right]\left[\mathrm{NTf}_{2}\right]^{46}$ at atmospheric pressure and temperature in the range (293.15 to 348.15$) \mathrm{K}$, where the viscosity of both ILs is $<100 \mathrm{mPa} \cdot \mathrm{s}$, allowed us to calculate an average density uncertainty less than $0.5 \mathrm{~kg} \cdot \mathrm{m}^{-3}$. For other ILs and/or other higher pressures where the viscosity increases, the correction value was assumed as $0.5 \mathrm{~kg} \cdot \mathrm{m}^{-3}$, being less than the uncertainty in the overall density data, which is $1 \mathrm{~kg} \cdot \mathrm{m}^{-3}$, and for that reason, viscosity corrections were neglected in the present work.

\section{Results and Discussion}

Density Measurements. Density measurements were carried out at temperatures ranging from (293.15 to 393.15$) \mathrm{K}$ and 
Table 2. Experimental Density, $\rho$, Data for $\left[\mathrm{C}_{3} \mathrm{mpyr}\right]\left[\mathrm{NTf}_{2}\right]$ and $\left[\mathrm{C}_{4} \mathrm{mpyr}\right]\left[\mathrm{NTf}_{2}\right]$ as a Function of Temperature and Pressure

\begin{tabular}{|c|c|c|c|c|c|c|c|}
\hline \multirow[b]{2}{*}{$p / \mathrm{MPa}$} & \multicolumn{7}{|c|}{$\rho / \mathrm{kg} \cdot \mathrm{m}^{-3}$ at $T / \mathrm{K}$} \\
\hline & 293.15 & 303.15 & 313.15 & 323.15 & 333.15 & 353.15 & 393.15 \\
\hline \multicolumn{8}{|c|}{$\left[\mathrm{C}_{3} \mathrm{mpyr}\right]\left[\mathrm{NTf}_{2}\right]$} \\
\hline 0.10 & 1438.6 & 1428.6 & 1418.6 & 1408.7 & 1399.0 & 1380.0 & 1343.2 \\
\hline 1.00 & 1439.3 & 1429.3 & 1419.3 & 1409.4 & 1399.7 & 1380.8 & 1344.0 \\
\hline 2.00 & 1440.0 & 1430.0 & 1420.1 & 1410.1 & 1400.5 & 1381.7 & 1344.9 \\
\hline 3.00 & 1440.7 & 1430.8 & 1420.9 & 1411.0 & 1401.4 & 1382.5 & 1345.8 \\
\hline 4.00 & 1441.4 & 1431.6 & 1421.7 & 1411.8 & 1402.2 & 1383.4 & 1346.8 \\
\hline 5.00 & 1442.1 & 1432.2 & 1422.5 & 1412.6 & 1403.0 & 1384.3 & 1347.8 \\
\hline 7.50 & 1444.0 & 1434.1 & 1424.3 & 1414.4 & 1405.0 & 1386.4 & 1350.2 \\
\hline 10.00 & 1445.8 & 1435.9 & 1426.3 & 1416.3 & 1407.0 & 1388.5 & 1352.5 \\
\hline 15.00 & 1449.2 & 1439.4 & 1429.9 & 1420.1 & 1410.8 & 1392.6 & 1357.1 \\
\hline 20.00 & 1452.6 & 1443.0 & 1433.4 & 1423.8 & 1414.6 & 1396.6 & 1361.5 \\
\hline 25.00 & 1456.0 & 1446.4 & 1436.9 & & 1418. & 1400.4 & 1365. \\
\hline 30.00 & 1459.2 & 1449.7 & 1440.3 & 1431.0 & 1421.9 & 1404.2 & 1370.0 \\
\hline 35.00 & 1462.3 & 1453.0 & 1443.6 & 1434.4 & 1425.4 & 1407.9 & 1374.0 \\
\hline \multicolumn{8}{|c|}{$\left[\mathrm{C}_{4} \mathrm{mpyr}\right]\left[\mathrm{NTf}_{2}\right]$} \\
\hline 0.10 & 1409.1 & 1399.3 & 1389.5 & 1379.8 & 1370.2 & 1351.5 & 1315.2 \\
\hline 1.00 & 1409.7 & 1399.9 & 1390.1 & 1380.4 & 1370.9 & 1352.3 & 1316.1 \\
\hline 2.00 & 1410.5 & 1400.7 & 1390.9 & 1381.2 & 1371.7 & 1353.2 & 1317.1 \\
\hline 3.00 & 1411.2 & 1401.4 & 1391.7 & 1382.0 & 1372.5 & 1354.1 & 1318.1 \\
\hline 4.00 & 1411.9 & 1402.2 & 1392.5 & 1382.8 & 1373.4 & 1354.9 & 1319.1 \\
\hline 5.00 & 1412.6 & 1402.9 & 1393.3 & 1383.6 & 1374.2 & 1355.8 & 1320.0 \\
\hline 7.50 & 1414.4 & 1404.8 & 1395.2 & 1385.6 & 1376.1 & 1357.9 & 1322.5 \\
\hline 10.00 & 1416.1 & 1406.6 & 1397.0 & 1387.5 & 1378.1 & 1360.0 & 1324. \\
\hline 15.00 & 1419.6 & 1410.1 & 1400.7 & 1391.3 & 1382.0 & 1364.1 & 1329.5 \\
\hline 20.00 & 1423.0 & 1413.6 & 1404.3 & 1394.9 & 1385.8 & 1368.1 & 1333.7 \\
\hline 25.00 & 1426.3 & 1417.0 & 1407.7 & 1398.5 & 1389.5 & 1371.9 & 1338.0 \\
\hline 30.00 & 1429.6 & 1420.3 & 1411.1 & 1402.0 & 1393.1 & 1375.7 & 1342.2 \\
\hline 35.00 & 1432.8 & 1423.6 & 1414.4 & 1405.4 & 1396.6 & 1379.4 & 1346.2 \\
\hline
\end{tabular}

pressures from (0.10 to 35.00) $\mathrm{MPa}$. The experimental data obtained are reported in Tables 1 and 2 for all the ILs studied.

Density data for some of the studied ILs are already available in the open literature but only at atmospheric pressure,,$^{27,45-50}$ and the relative deviations between the experimental data obtained in this work are presented in Figure 1. To the best of our knowledge, no literature data on densities were previously available for $\left[\mathrm{C}_{3} \mathrm{mpy}\right]\left[\mathrm{NTf}_{2}\right]$ and $\left[\mathrm{C}_{3} \mathrm{mpip}\right]\left[\mathrm{NTf}_{2}\right]$. Experimental data for $\left[\mathrm{C}_{2} \mathrm{mim}\right]\left[\mathrm{CF}_{3} \mathrm{SO}_{3}\right],\left[\mathrm{C}_{3} \mathrm{mpyr}\right]\left[\mathrm{NTf}_{2}\right]$, and $\left[\mathrm{C}_{4} \mathrm{mpyr}\right]\left[\mathrm{NTf}_{2}\right]$ are in good agreement with available literature values, the relative deviations ranging from ( -1.0 to 0.9$) \%$. Experimental density values are lower (within $1.0 \%$ ) than Rodriguez and Brennecke, ${ }^{45}$ Arce et al., ${ }^{47}$ and Vercher et al. ${ }^{48}$ for $\left[\mathrm{C}_{2} \mathrm{mim}\right]\left[\mathrm{CF}_{3} \mathrm{SO}_{3}\right]$. The same deviations are obtained for $\left[\mathrm{C}_{3} \mathrm{mpyr}\right]\left[\mathrm{NTf}_{2}\right]$ and $\left[\mathrm{C}_{4} \mathrm{mpyr}\right]\left[\mathrm{NTf}_{2}\right]$ when compared with MacFarlane et al. ${ }^{49}$ The data of $\left[\mathrm{C}_{4} \mathrm{mpyr}\right]\left[\mathrm{NTf}_{2}\right]$ are higher (within $0.9 \%$ ) than the values of Tokuda et al. ${ }^{46}$ and Anthony et al. ${ }^{50}$ and show both negative and positive deviations (ranging from $-0.7 \%$ to $0.7 \%$ ) from the values of Kato and Gmehling. ${ }^{27}$ These deviations can be due essentially to the salt's purity including water and halide content and also to the experimental technique adopted.

From the experimental densities for a given anion, it is observed that as the alkyl chain length in the pyrrolidinium cation increases the density of the corresponding IL decreases, similar to that observed for imidazolium-based ILs. ${ }^{37}$ The average molar volume change of $(16.2 \pm 0.5) \mathrm{cm}^{3} \cdot \mathrm{mol}^{-1}$ is observed in the measured data by the addition of a $-\mathrm{CH}_{2}$ group to the pyrrolidinum cation, whereas considering our previous data ${ }^{36}$ for $\left[\mathrm{C}_{4} \mathrm{mim}\right]\left[\mathrm{CF}_{3} \mathrm{SO}_{3}\right]$, it is $(16.4 \pm 0.5) \mathrm{cm}^{3} \cdot \mathrm{mol}^{-1}$ for the addition of a $-\mathrm{CH}_{2}$ group to the imidazolium cation which is in good agreement with the our previous work ${ }^{36,37}$ and also the works by Azevedo et al..$^{22,23}$ and Esperança et al..$^{24,25}$ and is anion-size independent.

The molar volumes for a series of ionic liquids with the same anion, $\left[\mathrm{NTf}_{2}\right]^{-}$, seem to increase with the effective cation size

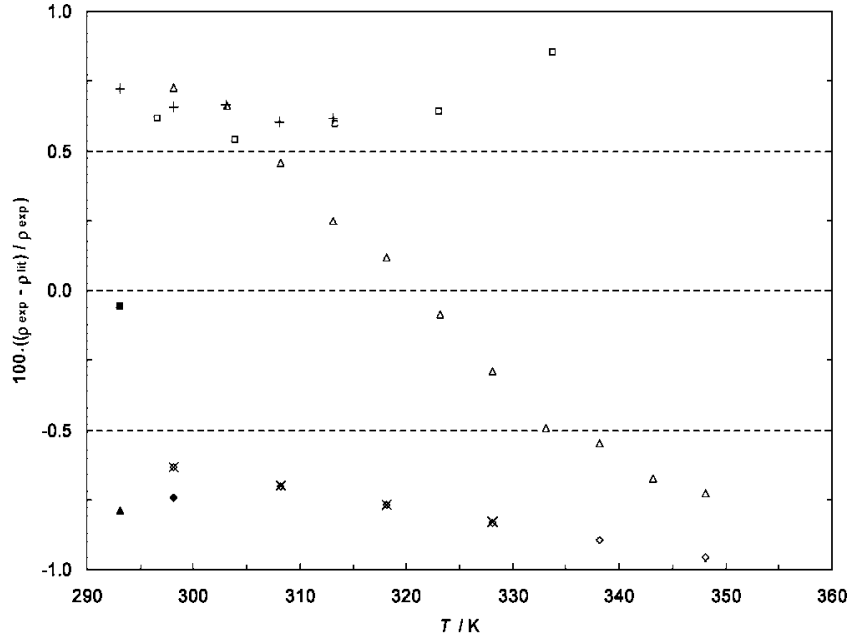

Figure 1. Relative deviations between the experimental density data of this work and those reported in the literature as a function of temperature at $0.10 \mathrm{MPa}$. $\left[\mathrm{C}_{2} \mathrm{mim}\right]\left[\mathrm{CF}_{3} \mathrm{SO}_{3}\right]: \diamond$, Rodriguez and Brennecke, ${ }^{45}$ - Arce et al. $;^{47} \times$, Vercher et al. ${ }^{48}\left[\mathrm{C}_{3} \mathrm{mpyr}\right]\left[\mathrm{NTf}_{2}\right]: \mathbf{\Delta}$, MacFarlane et al. ${ }^{49}\left[\mathrm{C}_{4} \mathrm{mpyr}\right]\left[\mathrm{NTf}_{2}\right]: \Delta$, Kato and Gmehling; ${ }^{27}+$, Tokuda et al.; ${ }^{46}$ $\square$, Anthony et al. ${ }^{50} \mathbf{\square}$, MacFarlane et al. ${ }^{49}$

in the order $\left[\mathrm{C}_{3}\right.$ mim $]<\left[\mathrm{C}_{3}\right.$ mpyr $] \leq\left[\mathrm{C}_{3}\right.$ mpy $]<\left[\mathrm{C}_{3}\right.$ mpip $]$, by taking into account the results for $\left[\mathrm{C}_{3} \mathrm{mim}\right]\left[\mathrm{NTf}_{2}\right]$ from Esperança et al. ${ }^{25}$ The molar volumes for $\left[\mathrm{C}_{2} \mathrm{mim}\right]^{+}$increase with the effective anion size in the order $\left[\mathrm{CF}_{3} \mathrm{SO}_{3}\right]<\left[\mathrm{NTf}_{2}\right]$, and by taking into account the results of our previous papers, ${ }^{36,37}$ they show the same trend, $\left[\mathrm{C}(\mathrm{CN})_{3}\right]<\left[\mathrm{BF}_{4}\right]<\left[\mathrm{PF}_{6}\right]<$ $\left[\mathrm{CF}_{3} \mathrm{SO}_{3}\right]<\left[\mathrm{NTf}_{2}\right]$. Due to differences in molecular weight, this effect is not directly translated in a similar dependence in the densities. The results of this study indicate that the densities of ILs from families other than the imidazolium can be manipulated by judicious selection of the cation and anion. A regular increase in the molar volume with the addition of $-\mathrm{CH}_{2}$ groups to the cation alkyl chain length was observed.

Derived Thermodynamic Properties. The liquid densities were correlated with the Tait equation, ${ }^{38}$ and other thermodynamic properties such as the isothermal compressibility, $\kappa_{T}$, the isobaric expansivity, $\alpha_{p}$, and the thermal pressure coefficient, $\gamma_{v}$, were calculated and reported as Supporting Information. The results show that the Tait equation correlates well the pure ILs studied with an average absolute relative deviation (AARD) inferior to $0.02 \%$.

The following form of the Tait equation ${ }^{38}$

$$
\rho=\frac{\rho(T, P=0.1 \mathrm{MPa})}{\left\{1-C \ln \frac{(B+P)}{(B+0.1)}\right\}}
$$

where

$$
\rho(T, P=0.1 \mathrm{MPa})=a_{1}+a_{2} T+a_{3} T^{2}
$$

was fitted to the density data. In eq $2, a_{1}, a_{2}$, and $a_{3}$ were found by fitting to the experimental $\rho(T, P=0.1 \mathrm{MPa})$ and are given in Table 3.

Coefficient $B$ is defined as

$$
B=b_{1}+\frac{b_{2}}{T}
$$

The coefficients $C, b_{1}$, and $b_{2}$ were obtained by fitting the Tait equation to experimental data, and their values along with thestandard deviation $\sigma$ of fit are given in Table 4. The standard deviation is defined by 


$$
\sigma=\left[\sum_{i=1}^{N_{\mathrm{p}}}\left(\rho_{\text {calcd }}-\rho_{\text {exptl }}\right)_{i}^{2} /\left(N_{\mathrm{p}}-k\right)\right]^{1 / 2}
$$

where $N_{\mathrm{p}}$ represents the number of data points $\left(N_{\mathrm{p}}=91\right)$ and $k$ is the number of adjusted parameters $(k=3)$. The average absolute relative deviation (AARD) was defined as

$$
\mathrm{AARD}=\frac{\sum_{i=1}^{N_{\mathrm{p}}} \mathrm{l}\left(\rho_{\text {calcd }}-\rho_{\text {expt } \mathrm{l}}\right) / \rho_{\text {exptl }} \mathrm{l}_{i}}{N_{\mathrm{p}}}
$$

and is listed in Table 4. Figure 2 shows the good agreement between the experimental density data and isotherms obtained with the Tait equation.

The Tait equation is an integrated form of an empirical equation representative of the isothermal compressibility behavior versus pressure. The effect of pressure in density can be best described by the isothermal compressibility, $\kappa_{T}$, which is calculated according to the following expression

$$
k_{T}=-\frac{1}{V_{\mathrm{m}}}\left(\frac{\partial V_{\mathrm{m}}}{\partial P}\right)_{T}=\frac{1}{\rho}\left(\frac{\partial \rho}{\partial P}\right)_{T}=\left(\frac{\partial \ln \rho}{\partial P}\right)_{T}
$$

where $\rho$ is the density and $P$ the pressure at constant temperature, $T$. The isothermal compressibilities can be calculated using eqs 1 and 6

$$
k_{T}=\left(\frac{C}{B+P}\right)\left(\frac{\rho}{\rho(T, P=0.1 \mathrm{MPa})}\right)
$$

For illustration purposes, the isothermal compressibilities of $\left[\mathrm{C}_{3} \mathrm{mpy}\right]\left[\mathrm{NTf}_{2}\right]$ are shown in Figure 3 . The ILs become more compressible with increasing temperature and less compressible with increasing pressure. The calculated values of $k_{T}$ are presented in the Supporting Information, as Tables ST1. In the studied range of temperature (293.15 to 393.15 ) K and pressure (0.10 to 35.00 ) $\mathrm{MPa}$, the isothermal compressibility range in $\mathrm{GPa}^{-1}$ is 0.380 to $0.577,0.438$ to $0.777,0.431$ to $0.726,0.435$ to 0.754 , and 0.415 to 0.749 , respectively, for $\left[\mathrm{C}_{2} \mathrm{mim}\right]\left[\mathrm{CF}_{3} \mathrm{SO}_{3}\right],\left[\mathrm{C}_{3} \mathrm{mpy}\right]\left[\mathrm{NTf}_{2}\right]$, $\left[\mathrm{C}_{3} \mathrm{mpyr}\right]\left[\mathrm{NTf}_{2}\right],\left[\mathrm{C}_{4} \mathrm{mpyr}\right]\left[\mathrm{NTf}_{2}\right]$, and $\left[\mathrm{C}_{3} \mathrm{mpip}\right]\left[\mathrm{NTf}_{2}\right]$. The isothermal compressibilities for a series of ionic liquids with the same anion, $\left[\mathrm{NTf}_{2}\right]^{-}$, seem to increase in the order $\left[\mathrm{C}_{3}\right.$ mpip $]<\left[\mathrm{C}_{3} \mathrm{mpyr}\right]$ $<\left[\mathrm{C}_{3} \mathrm{mpy}\right]$. Unfortunately, there is no literature data available for the isothermal compressibility comparison of the studied ILs. From the law of propagation of errors, we have found, by the analysis

\begin{tabular}{|c|c|c|c|c|}
\hline & $a_{1}$ & $a_{2}$ & $a_{3} \cdot 10^{4}$ & $\sigma$ \\
\hline IL & $\overline{\mathrm{kg} \cdot \mathrm{m}^{-3}}$ & $\overline{\mathrm{kg} \cdot \mathrm{m}^{-3} \cdot \mathrm{K}^{-1}}$ & $\overline{\mathrm{kg} \cdot \mathrm{m}^{-3} \cdot \mathrm{K}^{-2}}$ & $\overline{\mathrm{kg} \cdot \mathrm{m}^{-3}}$ \\
\hline$\left[\mathrm{C}_{2} \mathrm{mim}\right]\left[\mathrm{CF}_{3} \mathrm{SO}_{3}\right]$ & 1699.418 & -1.2449 & 5.248 & 0.09 \\
\hline$\left[\mathrm{C}_{3} \mathrm{mpy}\right]\left[\mathrm{NTf}_{2}\right]$ & 1807.635 & -1.3551 & 5.172 & 0.09 \\
\hline$\left[\mathrm{C}_{3} \mathrm{mpyr}\right]\left[\mathrm{NTf}_{2}\right]$ & 1786.720 & -1.3614 & 5.935 & 0.05 \\
\hline$\left[\mathrm{C}_{4} \mathrm{mpyr}\right]\left[\mathrm{NTf}_{2}\right]$ & 1747.237 & -1.3129 & 5.444 & 0.05 \\
\hline$\left[\mathrm{C}_{3} \mathrm{mpip}\right]\left[\mathrm{NTf}_{2}\right]$ & 1776.104 & -1.4293 & 6.990 & 0.39 \\
\hline
\end{tabular}
of all studied ILs, that the minimum uncertainty in $k_{T}$ was $\pm 2 \cdot 10^{-3}$

Table 3. Coefficients of Equation 2, along with Standard Deviation of the Fit $(\sigma)$

\begin{tabular}{|c|c|c|c|c|c|}
\hline \multirow[b]{2}{*}{ liquid } & \multirow[b]{2}{*}{$C$} & $b_{1}$ & $b_{2} \cdot 10^{-4}$ & $\sigma$ & \multirow[b]{2}{*}{ AARD/\% } \\
\hline & & $\mathrm{MPa}$ & $\mathrm{MPa} \cdot \mathrm{K}$ & $\mathrm{kg} \cdot \mathrm{m}^{-3}$ & \\
\hline$\left[\mathrm{C}_{2} \mathrm{mim}\right]\left[\mathrm{CF}_{3} \mathrm{SO}_{3}\right]$ & 0.10547 & -3.9665 & 7.3426 & 0.10 & 0.01 \\
\hline$\left[\mathrm{C}_{3} \mathrm{mpy}\right]\left[\mathrm{NTf}_{2}\right]$ & 0.08002 & -37.156 & 5.5043 & 0.15 & 0.01 \\
\hline$\left[\mathrm{C}_{3} \mathrm{mpyr}\right]\left[\mathrm{NTf}_{2}\right]$ & 0.09097 & -33.353 & 6.2336 & 0.10 & 0.01 \\
\hline$\left[\mathrm{C}_{4} \mathrm{mpyr}\right]\left[\mathrm{NTf}_{2}\right]$ & 0.08782 & -41.507 & 6.2097 & 0.09 & 0.01 \\
\hline$\left[\mathrm{C}_{3}\right.$ mpip $]\left[\mathrm{NTf}_{2}\right]$ & 0.07924 & -50.494 & 6.1401 & 0.30 & 0.02 \\
\hline
\end{tabular}

Table 4. Coefficients of Equations 1 and 3, along with Standard Deviation of the Fit $(\sigma)$ and Average Absolute Relative Deviation (AARD) of Equation 1

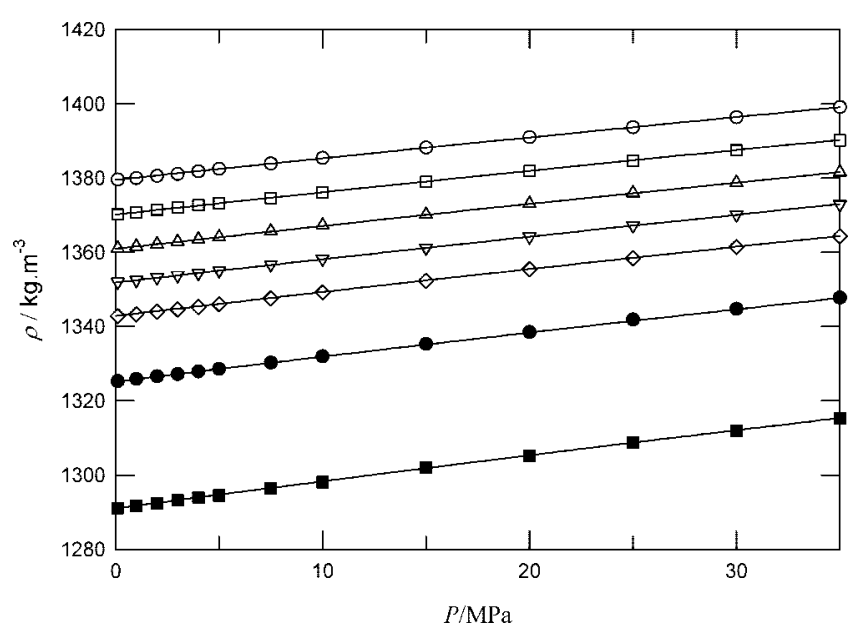

Figure 2. Isotherms of the density, $\rho$, for $\left[\mathrm{C}_{2} \mathrm{mim}\right]\left[\mathrm{CF}_{3} \mathrm{SO}_{3}\right]$. The symbols refer to the experimental data: $\bigcirc, 293.15 \mathrm{~K} ; \square, 303.15 \mathrm{~K} ; \Delta, 313.15 \mathrm{~K} ; \nabla$, $323.15 \mathrm{~K} ; \diamond, 333.15 \mathrm{~K} ; \bullet \cdot 353.15 \mathrm{~K} ; \mathbf{\square}, 393.15 \mathrm{~K}$. The curves are calculated with Tait equation, eq 1.

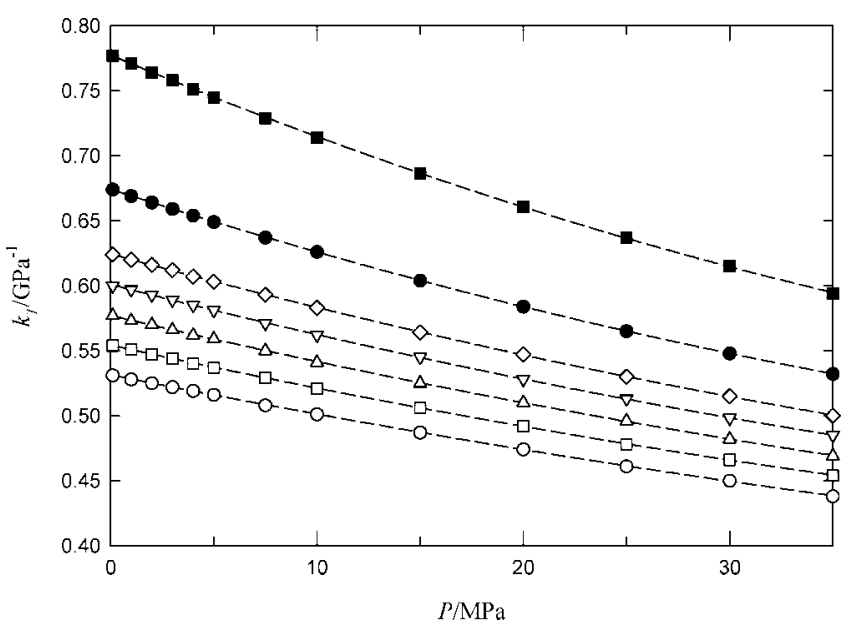

Figure 3. Isotherms for the isothermal compressibility of $\left[\mathrm{C}_{3} \mathrm{mpy}\right]\left[\mathrm{NTf}_{2}\right]$ : O, $293.15 \mathrm{~K} ; \square, 303.15 \mathrm{~K} ; \Delta, 313.15 \mathrm{~K} ; \nabla, 323.15 \mathrm{~K} ; \diamond, 333.15 \mathrm{~K} ; \bullet$, $353.15 \mathrm{~K} ; \mathbf{\square}, 393.15 \mathrm{~K}$. The curves were fitted to data.

$\mathrm{GPa}^{-1}$ (at $293.15 \mathrm{~K}, 35 \mathrm{MPa}$ ), and the maximum was $\pm 0.5 \mathrm{GPa}^{-1}$ (at $393.15 \mathrm{~K}, 0.1 \mathrm{MPa}$ ).

The IL isothermal compressibilities are similar to those of water and high-temperature molten salts and are less compressible than organic solvents due to the strong Coulombic interactions between the ions. ${ }^{29,51}$

The isobaric expansivity, $\alpha_{P}$ is defined as

$$
\alpha_{P}=\frac{1}{V_{\mathrm{m}}}\left(\frac{\partial V_{\mathrm{m}}}{\partial T}\right)_{P}=-\frac{1}{\rho}\left(\frac{\partial \rho}{\partial T}\right)_{P}=-\left(\frac{\partial \ln \rho}{\partial T}\right)_{P}
$$

and the following expression is derived from the Tait equation, eq 1

$$
\begin{aligned}
\alpha_{P}=-\left\{\frac{[\mathrm{d} \rho(T, P=0.1 \mathrm{MPa}) / \mathrm{d} T]}{\rho(T, P=0.1 \mathrm{MPa})}\right\}+ \\
C\left\{\frac{\frac{\mathrm{d} B}{\mathrm{~d} T}(P-0.1)}{\left[1-C \ln \left(\frac{B+P}{B+0.1}\right)\right](B+0.1)(B+P)}\right\}
\end{aligned}
$$

where $\mathrm{d} B / \mathrm{d} T=-b_{2} / T^{2}$. The values of $\alpha_{p}$ are presented in the Supporting Information, as Tables ST2, for all investigated ILs.

The $\alpha_{p}$ decreases with temperature as shown in Figure 4 for $\left[\mathrm{C}_{3}\right.$ mpyr $]\left[\mathrm{NTf}_{2}\right]$; nevertheless, the ILs studied do not notably 


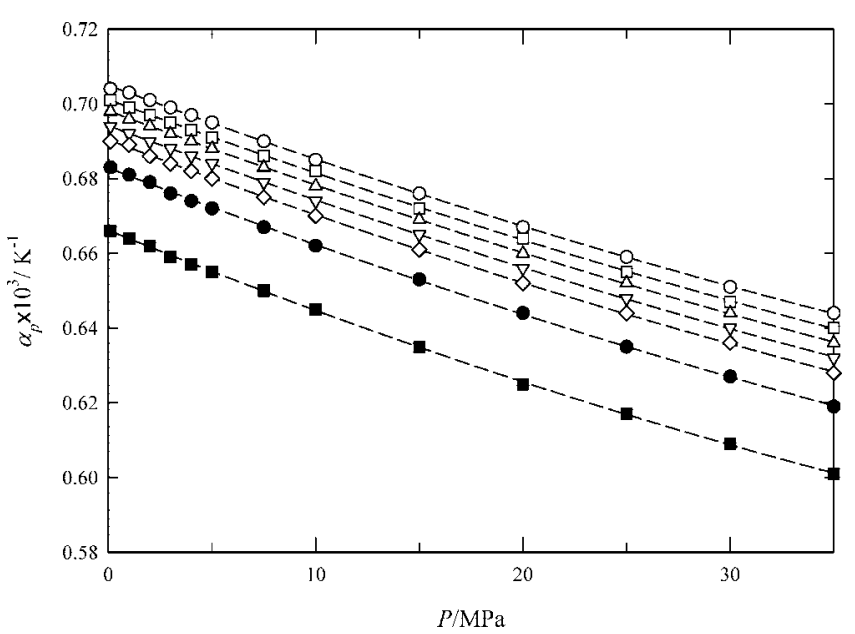

Figure 4. Isotherms for the isobaric expansivity of $\left[\mathrm{C}_{3} \operatorname{mpyr}\right]\left[\mathrm{NTf}_{2}\right]$ : $\mathrm{O}$, $293.15 \mathrm{~K} ; \square, 303.15 \mathrm{~K} ; \Delta, 313.15 \mathrm{~K} ; \nabla, 323.15 \mathrm{~K} ; \diamond, 333.15 \mathrm{~K} ; \bullet, 353.15$ $\mathrm{K} ; \mathbf{\square}, 393.15 \mathrm{~K}$. The curves were fitted to data.

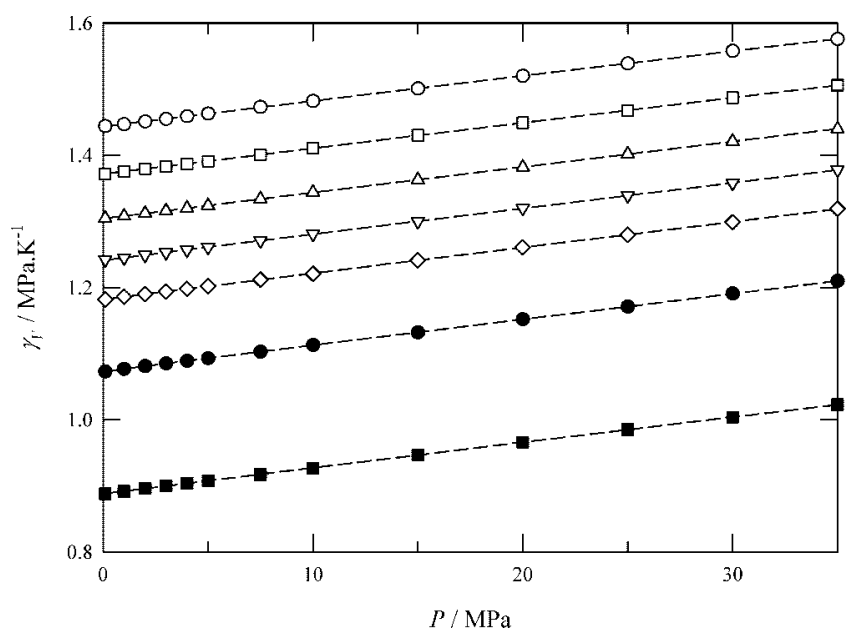

Figure 5. Isotherms for the thermal pressure coefficient of $\left[\mathrm{C}_{3} \operatorname{mpip}\right]\left[\mathrm{NTf}_{2}\right]$ : ○, 293.15 K; $\square, 303.15 \mathrm{~K} ; \Delta, 313.15 \mathrm{~K} ; \nabla, 323.15 \mathrm{~K} ; \diamond, 333.15 \mathrm{~K} ; \bullet$, $353.15 \mathrm{~K} ; \mathbf{\square}, 393.15 \mathrm{~K}$. The curves were fitted to data.

expand with temperature. However, there are some ILs that present more significant decreases in $\alpha_{p}$ with temperature, ${ }^{52}$ but in fact, ILs do not expand markedly with temperature and have $\alpha_{p}$ values lower than most organic liquids and similar to that of water. From eq 9, the isobaric expansivity, for the studied range of temperature (293.15 to 393.15$) \mathrm{K}$ and pressure $(0.10$ to 35.00$) \mathrm{MPa}$, is $\{(0.600$ to 0.679$) \cdot 10^{-3},(0.628$ to 0.723$) \cdot 10^{-3},(0.601$ to 0.704$) \cdot 10^{-3}$, $(0.601$ to 0.705$) \cdot 10^{-3}$, and $(0.590$ to 0.719$\left.) \cdot 10^{-3}\right\} \mathrm{K}^{-1}$, respectively, for $\left[\mathrm{C}_{2} \mathrm{mim}\right]\left[\mathrm{CF}_{3} \mathrm{SO}_{3}\right],\left[\mathrm{C}_{3} \mathrm{mpy}\right]\left[\mathrm{NTf}_{2}\right],\left[\mathrm{C}_{3} \mathrm{mpyr}\right]\left[\mathrm{NTf}_{2}\right]$, $\left[\mathrm{C}_{4} \mathrm{mpyr}\right]\left[\mathrm{NTf}_{2}\right]$, and $\left[\mathrm{C}_{3} \mathrm{mpip}\right]\left[\mathrm{NTf}_{2}\right]$. A similar procedure is that used for $k_{T}$ which allows us to determine the uncertainties in $\alpha_{p}$. The minimum value was $\pm 1 \cdot 10^{-5} \mathrm{~K}^{-1}$ (at $293.15 \mathrm{~K}, 0.1 \mathrm{MPa}$ ), and the maximum was $\pm 7 \cdot 10^{-4} \mathrm{~K}^{-1}$ (at $393.15 \mathrm{~K}, 35 \mathrm{MPa}$ ).

The thermal pressure coefficient, $\gamma_{v}$, may be calculated according to

$$
\gamma_{v}=\frac{\alpha_{p}}{\kappa_{T}}
$$

The thermal pressure coefficients as a function of pressure obtained for investigated ILs are shown in Figure 5 for $\left[\mathrm{C}_{3}\right.$ mpip] $\left[\mathrm{NTf}_{2}\right]$. The $\gamma_{v}$ decreases with temperature and increases slightly with pressure for all the ILs studied (see Supporting Information, Table ST3). The uncertainties in $\gamma_{v}$ were determined with the law of propagation of errors from
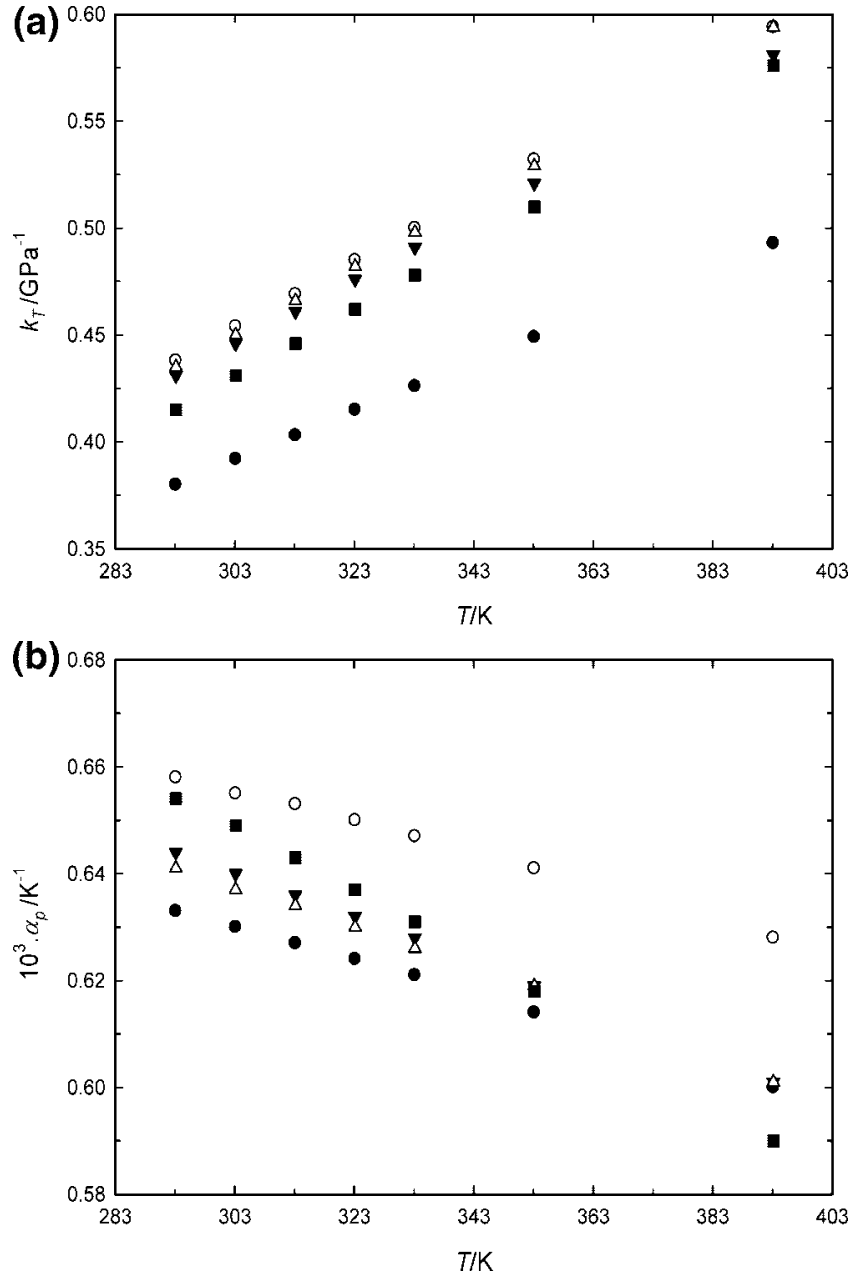

Figure 6. (a) Isothermal compressibility at $35.00 \mathrm{MPa}$ as a function of temperature. (b) Isobaric expansivity at $35.00 \mathrm{MPa}$ as a function of temperature for: $\bullet,\left[\mathrm{C}_{2} \mathrm{mim}\right]\left[\mathrm{CF}_{3} \mathrm{SO}_{3}\right] ; \quad \mathrm{O}, \quad\left[\mathrm{C}_{3} \mathrm{mpy}\right]\left[\mathrm{NTf}_{2}\right] ; \quad \boldsymbol{\nabla}$, $\left[\mathrm{C}_{3} \mathrm{mpyr}\right]\left[\mathrm{NTf}_{2}\right] ; \Delta,\left[\mathrm{C}_{4} \mathrm{mpyr}\right]\left[\mathrm{NTf}_{2}\right]$; and $\mathbf{m},\left[\mathrm{C}_{3} \mathrm{mpip}\right]\left[\mathrm{NTf}_{2}\right]$.

those of $\alpha_{p}$ and $\kappa_{T}$. We have obtained high uncertainties of the same magnitude of the thermal pressure coefficient.

A comparison for the isothermal compressibilities and isobaric thermal expansivities as a function of temperature at a constant pressure of $35.00 \mathrm{MPa}$ for the ILs studied is presented in Figure 6. By considering the studied pyrrolidinium-based ILs, Figure $6 \mathrm{a}$, there is an indication that the ILs with higher molar volumes are generally more compressible since the $\kappa_{T}$ increases with the alkyl chain length of the cation. This behavior of pyrrolidiniumbased ILs is similar to previously studied imidazolium-based ILs. ${ }^{36,37}$ Moreover, by considering the studied ILs having the same anion, $\left[\mathrm{NTf}_{2}\right]^{-}$, the influence of the cation on the isothermal compressibility and isobaric thermal expansivity is not very pronounced unlike that previously observed for imidazolium-based ILs with different anions. ${ }^{36,37}$

Density Modeling. Recently, we proposed a new method ${ }^{39}$ for the estimation of ionic liquid densities in a wide range of temperatures (273.15 to 393.15 ) $\mathrm{K}$ and pressures (0.10 to 100 ) $\mathrm{MPa}$, according to eq 11

$$
\rho=\frac{M}{N V(a+b T+c P)}
$$

where $\rho$ is the density in $\mathrm{kg} \cdot \mathrm{m}^{-3} ; M$ is the molar mass in $\mathrm{kg} \cdot \mathrm{mol}^{-1} ; N$ is the Avogadro constant; $V$ is the molecular volume in $\AA^{3} ; T$ is the temperature in $\mathrm{K}$; and $P$ is the pressure in MPa. The coefficients $a, b$, and $c$ were estimated by fitting 
Table 5. Calculated Densities by Using Equation 11, Molar Mass $(M)$, Molecular Volume $(V)$, Experimental Average Density $\left(\rho_{\text {exptl-av }}\right)$, Calculated Average Density ( $\rho_{\text {calcd-av }}$ ), and Average Absolute Relative Deviation (AARD) of Ionic Liquids

\begin{tabular}{|c|c|c|c|c|c|c|c|}
\hline \multirow[b]{2}{*}{ ionic liquid } & \multirow{2}{*}{$\frac{M}{\mathrm{~g} \cdot \mathrm{mol}^{-1}}$} & \multicolumn{2}{|c|}{$V / \AA^{3}$} & \multirow[b]{2}{*}{ data points } & \multirow{2}{*}{$\frac{\rho_{\text {exptl-av }}}{\mathrm{kg} \cdot \mathrm{m}^{-3}}$} & \multirow{2}{*}{$\frac{\rho_{\text {calcd-av }}}{\mathrm{kg} \cdot \mathrm{m}^{-3}}$} & \multirow{2}{*}{$\frac{\mathrm{AARD}}{\%}$} \\
\hline & & cation & anion & & & & \\
\hline$\left[\mathrm{C}_{2} \mathrm{mim}\right]\left[\mathrm{CF}_{3} \mathrm{SO}_{3}\right]$ & 260.24 & 182 & 129 & 91 & 1353.5 & 1371.4 & 1.32 \\
\hline$\left[\mathrm{C}_{3} \mathrm{mpy}\right]\left[\mathrm{NTf}_{2}\right]$ & 416.37 & 230 & 248 & 91 & 1426.8 & 1427.6 & 0.11 \\
\hline$\left[\mathrm{C}_{3} \mathrm{mpyr}\right]\left[\mathrm{NTf}_{2}\right]$ & 408.39 & 225 & 248 & 91 & 1411.7 & 1415.0 & 0.24 \\
\hline$\left[\mathrm{C}_{4} \mathrm{mpyr}\right]\left[\mathrm{NTf}_{2}\right]$ & 422.41 & 253 & 248 & 91 & 1382.8 & 1381.8 & 0.11 \\
\hline$\left[\mathrm{C}_{3}\right.$ mpip $]\left[\mathrm{NTf}_{2}\right]$ & 422.41 & $250^{a}$ & 248 & 91 & - & - & - \\
\hline
\end{tabular}

${ }^{a}$ Calculated in this work.

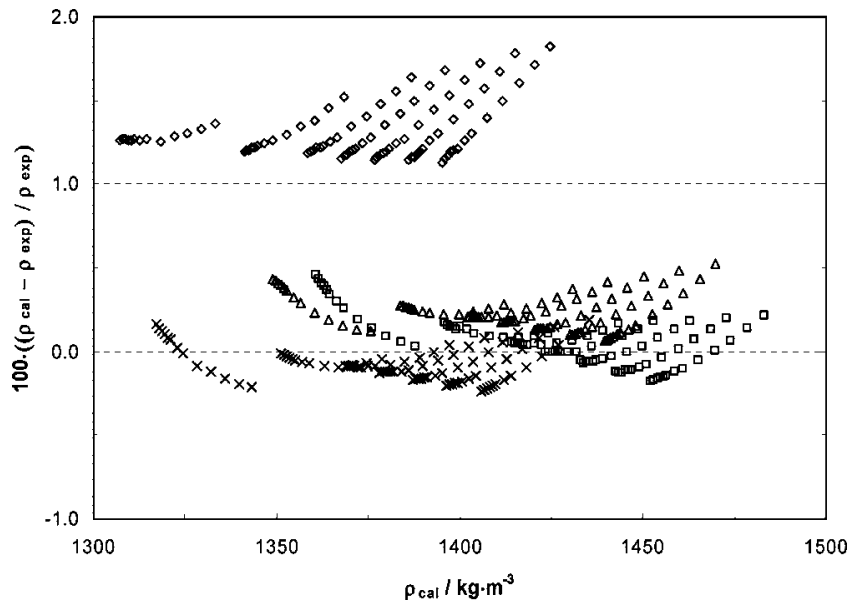

Figure 7. Relative deviations between the experimental and calculated density data as a function of calculated densities using eq 11 for ionic liquids: $\diamond, \quad\left[\mathrm{C}_{2} \mathrm{mim}\right]\left[\mathrm{CF}_{3} \mathrm{SO}_{3}\right] ; \quad \square, \quad\left[\mathrm{C}_{3} \mathrm{mpy}\right]\left[\mathrm{NTf}_{2}\right] ; \Delta, \quad\left[\mathrm{C}_{3} \mathrm{mpyr}\right]\left[\mathrm{NTf}_{2}\right] ; \times$, $\left[\mathrm{C}_{4} \mathrm{mpyr}\right]\left[\mathrm{NTf}_{2}\right]$.

eq 11 to our previously published experimental data. ${ }^{36,37}$ A total amount of ca. 800 density data points were used. The values of coefficients $a, b$, and $c$ obtained are $\left(8.005 \cdot 10^{-1} \pm 2 \cdot 10^{-4}\right)$, $\left(6.652 \cdot 10^{-4} \pm 7 \cdot 10^{-7}\right) \mathrm{K}^{-1}$, and $\left(-5.919 \cdot 10^{-4} \pm 2.4 \cdot 10^{-6}\right)$ $\mathrm{MPa}^{-1}$, respectively, at the $95 \%$ confidence level. The average absolute relative deviation of calculated densities from the experimental densities is $0.29 \%$. The experimental density $(Y)$, for the ILs used to obtain coefficients $a, b$, and $c$ of eq 11 , is essentially identical to its calculated density $(X): Y=(0.9998$ $\pm 0.0003) X$ (correlation coefficient: $R^{2}=0.9989$, at $95 \%$ level of confidence). For the density calculation, volume parameters $(V)$ of ions and groups were either directly taken from the literature $^{53}$ or calculated following the Jenkins procedure. ${ }^{54}$ The volume of the 1,1-dimethylpiperidinium cation is estimated in this work as $194 \AA^{3}$ by minimizing the objective function (OF)

$$
\mathrm{OF}=\frac{\sum_{i=1}^{N_{\mathrm{p}}} \mathrm{l}\left(\rho_{\text {calcd }}-\rho_{\text {exptt }}\right) / \rho_{\text {exptl }} \mathrm{l}_{i}}{N_{\mathrm{p}}}
$$

where $N_{\mathrm{p}}$ represents the number of data points $\left(N_{\mathrm{p}}=91\right)$ of $\left[\mathrm{C}_{3}\right.$ mpip] $\left[\mathrm{NTf}_{2}\right]$.

The densities of $\left[\mathrm{C}_{2} \mathrm{mim}\right]\left[\mathrm{CF}_{3} \mathrm{SO}_{3}\right],\left[\mathrm{C}_{3} \mathrm{mpy}\right]\left[\mathrm{NTf}_{2}\right],\left[\mathrm{C}_{3} \mathrm{mpyr}\right]$ $\left[\mathrm{NTf}_{2}\right]$, and $\left[\mathrm{C}_{4} \mathrm{mpyr}\right]\left[\mathrm{NTf}_{2}\right]$ were calculated by using eq 11 . Calculated densities with the average absolute deviation (AAD) of studied ILs are shown in Table 5. As shown in Figure 7, the experimental densities $(Y)$ of $\left[\mathrm{C}_{2} \mathrm{mim}\right]\left[\mathrm{CF}_{3} \mathrm{SO}_{3}\right],\left[\mathrm{C}_{3} \mathrm{mpy}\right]\left[\mathrm{NTf}_{2}\right]$, $\left[\mathrm{C}_{3} \mathrm{mpyr}\right]\left[\mathrm{NTf}_{2}\right]$, and $\left[\mathrm{C}_{4} \mathrm{mpyr}\right]\left[\mathrm{NTf}_{2}\right]$ display a very good agreement with the predicted densities $(X)$ from eq 12: $Y=$ $(0.9963 \pm 0.0003) X$ (correlation coefficient: $R^{2}=0.9874$, at $95 \%$ level of confidence).

These results show that the density estimation method proposed by Gardas and Coutinho ${ }^{39}$ can be applied with confidence to ionic liquids from families other than those used on the development of the correlation.

\section{Conclusions}

Experimental density data for five pure ILs in the temperature range (293.15 to 393.15$) \mathrm{K}$ and pressure range (0.10 to 35.00$)$ $\mathrm{MPa}$ are presented. Density results can be explained by structural variations in the cation and anion. From the experimental data, a proportional molar volume increase was observed with the alkyl chain length of the cation of ILs. The liquid densities were correlated with the Tait equation ${ }^{38}$ that has been shown to describe well all the pure ILs studied with an average absolute relative deviation (AARD) less than $0.02 \%$.

The experimental results were also used to estimate some derivative thermodynamic properties such as the isothermal compressibility, the isobaric expansivity, and the thermal pressure coefficient of the studied ILs that are difficult to obtain by direct measurements at extreme conditions of pressure and temperature.

The Gardas and Coutinho ${ }^{39}$ method for the prediction of ionic liquid densities was tested against the measured densities with excellent results showing that it applies to other ionic liquid families than those used for its development.

\section{Supporting Information Available:}

An additional three tables. This material is available free of charge via the Internet at http://pubs.acs.org.

\section{Literature Cited}

(1) Brennecke, J. F.; Maginn, E. J. Ionic liquids: innovative fluids for chemical processing. AIChE J. 2001, 47, 2384-2389.

(2) Sheldon, R. Catalytic reactions in ionic liquids. Chem Commun. 2001, 2399, 2407.

(3) Welton, T. Room-temperature ionic liquids. Solvents for synthesis and catalysis. Chem. Rev. 1999, 99, 2071-2083.

(4) Holbrey, J. D.; Seddon, K. R. Ionic Liquids. Clean Prod. Proc. 1999, 1, 223-236.

(5) Ionic Liquids in Synthesis; Wasserscheid, P., Welton, T., Eds.; WileyVCH: Weinheim, 2003.

(6) Ionic Liquids IIIA: Fundamentals, Progress, Challenges, and Opportunities; Seddon, K. R., Rogers, R. D., Eds.;ACS Symp. Ser.; American Chemical Society: Washington DC, 2005; Vol. 901.

(7) Ionic Liquids IIIB: Fundamentals, Progress, Challenges, and Opportunities-Transformations and Processes; Seddon, K. R., Rogers, R. D., Eds.; ACS Symp. Ser.; American Chemical Society: Washington DC, 2005; Vol. 902.

(8) Huddleston, J. G.; Willauer, H. D.; Swatloski, R. P.; Visser, A. E.; Rogers, R. D. Room Temperature Ionic Liquids as Novel Media for Clean Liquid-Liquid Extraction. Chem. Commun. 1998, 1765, 1766.

(9) Branco, L. C.; Crespo, J. G.; Afonso, C. A. M. Studies on the Selective Transport of Organic Compounds by Using Ionic Liquids as Novel Supported Liquid Membranes. Chem.-Eur. J. 2002, 8, 3865-3871.

(10) Hagiwara, R.; Ito, Y. Room temperature ionic liquids of alkylimidazolium cations and fluoroanions. J. Fluorine Chem. 2000, 105, 221227.

(11) Kragel, U.; Eckstein, M.; Kaftzik, N. Enzyme catalysis in ionic liquids. Curr. Opin. Biotechnol. 2002, 13, 565-571. 
(12) Scovazzo, P.; Kieft, J.; Finan, D. A.; Koval, C.; DuBois, D.; Noble, R. Gas Separations Using Non-Hexafluorophosphate $\left[\mathrm{PF}_{6}\right]^{-}$Anion Supported Ionic Liquid Membranes. J. Membr. Sci. 2004, 238, 5763.

(13) Davis, J. H., Jr. Task-Specific Ionic Liquids. Chem. Lett. 2004, 33, 1072-1077.

(14) Buzzeo, M. C.; Evans, R. G.; Compton, R. G. Non-Haloaluminate Room-Temperature Ionic Liquids in Electrochemistry - A Review. ChemPhysChem 2004, 5, 1106-1120.

(15) Gan, Q.; Rooney, D.; Xue, M.; Thompson, G.; Zou, Y. An experimental study of gas transport and separation properties of ionic liquids supported on nanofiltration membranes. J. Membr. Sci. 2006, 280, 948 956.

(16) Zhao, H. Innovative Applications of Ionic Liquids As "Green" Engineering Liquids. Chem. Eng. Commun. 2006, 193, 1660-1677.

(17) http://ilthermo.boulder.nist.gov/ILThermo/mainmenu.uix (accessed on 13, November 2007)

(18) Marsh, K. N.; Boxall, J. A.; Lichtenthaler, R. Room temperature ionic liquids and their mixtures - a review. Fluid Phase Equilib. 2004, 219 , 93-98

(19) Heintz, A. Recent developments in thermodynamics and thermophysics of non-aqueous mixtures containing ionic liquids. A review. J. Chem. Thermodyn. 2005, 37, 525-535.

(20) Zhang, S.; Sun, N.; He, X.; Lu, X.; Zhang, X. Physical Properties of Ionic Liquids: Database and Evaluation. J. Phys. Chem. Ref. Data 2006, 35, 1475-1517.

(21) Fredlake, C. P.; Crosthwaite, J. M.; Hert, D. G.; Aki, S. N. V. K.; Brennecke, J. F. Thermophysical properties of imidazolium-based ionic liquids. J. Chem. Eng. Data 2004, 49, 954-964.

(22) Azevedo, R. G.; Esperança, J. M. S. S.; Najdanovic-Visak, V.; Visak, Z. P.; Guedes, H. J. R.; Nunes da Ponte, M.; Rebelo, L. P. N. Thermophysical and Thermodynamic Properties of 1-Butyl-3-methylimidazolium Tetrafluoroborate and 1-Butyl-3-methylimidazolium Hexafluorophosphate over an Extended Pressure Range. J. Chem. Eng. Data 2005, 50, 997-1008

(23) Azevedo, R. G.; Esperança, J. M. S. S.; Szydlowski, J.; Visak, Z. P.; Pires, P. F.; Guedes, H. J. R.; Rebelo, L. P. N. Thermophysical and Thermodynamic Properties of Ionic Liquids over an Extended Pressure Range: $[\mathrm{bmim}]\left[\mathrm{NTf}_{2}\right]$ and $[\mathrm{hmim}]\left[\mathrm{NTf}_{2}\right]$. J. Chem. Thermodyn. 2005, 37, 888-899.

(24) Esperança, J. M. S. S.; Guedes, H. J. R.; Blesic, M.; Rebelo, L. P. N Densities and Derive Thermodynamic Properties of Ionic Liquids. 3. Phosphonium-Based Ionic Liquids over an Extended PressurRange. J. Chem. Eng. Data 2006, 51, 237-242.

(25) Esperança, J. M. S. S.; Visak, Z. P.; Plechkova, N. V.; Seddon, K. R.; Guedes, H. J. R.; Rebelo, L. P. N. Densities and Derive Thermodynamic Properties of Ionic Liquids. 3. [C3mim][NTf2] and [C5mim] [NTf2]. J. Chem. Eng. Data 2006, 51, 2009-2015.

(26) Troncoso, J.; Cerdeirina, C. A.; Sanmamed, Y. A.; Romani, L.; Rebelo, L. P. N. J. Chem. Eng. Data 2006, 51, 1856-1859.

(27) Kato, R.; Gmehling, J. Systems with ionic liquids: Measurement of VLE and c1 data and prediction of their thermodynamic behavior using original UNIFAC, mod. UNIFAC(Do) and COSMO-RS(Ol). J. Chem. Thermodyn. 2005, 37, 603-619.

(28) Pereiro, A. B.; Verdia, P.; Tojo, E.; Rodriguez, A. Physical Properties of 1-Butyl-3-methylimidazolium Methyl Sulfate as a Function of Temperature. J. Chem. Eng. Data 2007, 52, 377-380.

(29) Gu, Z.; Brennecke, J. F. Volume Expansivities and Isothermal Compressibilities of Imidazolium and Pyridinium-Based Ionic Liquids. J. Chem. Eng. Data 2002, 47, 339-345.

(30) Harris, K. R.; Woolf, L. A.; Kanakubo, M. Temperature and pressure dependence of the viscosity of the ionic liquid 1-butyl-3-methylimidazolium hexafluorophosphate. J. Chem. Eng. Data 2005, 50, 17771782 .

(31) Harris, K. R.; Kanakubo, M.; Woolf, L. A. Temperature and Pressure Dependence of the Viscosity of the Ionic Liquids 1-Methyl-3octylimidazolium Hexafluorophosphate and 1-Methyl-3-octylimidazolium Tetrafluoroborate. J. Chem. Eng. Data 2006, 51, 1161-1167.

(32) Kabo, G. J.; Blokhin, A. V.; Paulechka, Y. U.; Kabo, A. G.; Shymanovich, M. P.; Magee, J. W. Thermodynamic Properties of 1-Butyl-3-methylimidazolium Hexafluorophosphate in the Condensed State. J. Chem. Eng. Data 2004, 49, 453-461.

(33) Paulechka, Y. U.; Kabo, G. J.; Blokhin, A. V.; Shaplov, A. S.; Lozinskaya, E. I.; Vygodskii, Y. S. Thermodynamic properties of 1-alkyl-3-methylimidazolium bromide ionic liquids. J. Chem. Thermodyn. 2007, 39, 158-166.

(34) Crosthwaite, J. M.; Muldoon, M. J.; Dixon, J. K.; Anderson, J. L.; Brennecke, J. F. Phase transition and decomposition temperatures. Heat capacities and viscosities of pyridinium ionic liquids. J. Chem. Thermodyn. 2005, 37, 559-568.

(35) Papaiconomou, N.; Salminen, J.; Lee, J.-M.; Prausnitz, J. M. Physicochemical Properties of Hydrophobic Ionic Liquids Containing 1-Octylpyridinium, 1-Octyl-2-methylpyridinium, or 1-Octyl-4-methylpyridinium Cations. J. Chem. Eng. Data 2007, 52, 833-840.

(36) Gardas, R. L.; Freire, M. G.; Carvalho, P. J.; Marrucho, I. M.; Fonseca, I. M. A.; Ferreira, A. G. M.; Coutinho, J. A. P. High-Pressure Densities and Derived Thermodynamic Properties of Imidazolium-Based Ionic Liquids. J. Chem. Eng. Data 2007, 52, 80-88.

(37) Gardas, R. L.; Freire, M. G.; Carvalho, P. J.; Marrucho, I. M.; Fonseca, I. M. A.; Ferreira, A. G. M.; Coutinho, J. A. P. P $\rho$ T Measurements of Imidazolium Based Ionic Liquids. J. Chem. Eng. Data 2007, 52, 18811888.

(38) Dymond, J. H.; Malhotra, R. The Tait equation: 100 years on. Int. J. Thermophys. 1988, 9, 941-951.

(39) Gardas, R. L.; Coutinho, J. A. P. Extension of the Ye and Shreeve group contribution method for density estimation of ionic liquids in a wide range of temperatures and pressures. Fluid Phase Equilib. 2008, 263, 26-32.

(40) Gardas, R. L.; Johnson, I.; Vaz, D. M. D.; Fonseca, I. M. A.; Ferreira, A. G. M. PVT Property Measurements for Some Aliphatic Esters from (298 to 393) K and up to 35 MPa. J. Chem. Eng. Data 2007, 52, 737-751.

(41) Niesen, V. G. (Vapor + Liquid) Equilibria and Coexisting Densities of (Carbon Dioxide $+n$-butane) at 311 to 395 K. J. Chem. Thermodyn. 1990, 22, 777-795.

(42) Holcomb, C. D.; Outcalt, S. L. A Theoretical-Based Calibration and Evaluation Procedure for Vibrating-Tube Densimeters. Fluid Phase Equilib. 1998, 150-151, 815-827.

(43) Fandiño, O.; Pensado, A. S.; Lugo, L.; Comuñas, M. P. J.; Fernández, J. Compressed Liquid Densities os Squalane and Pentarythritol Tetra(2ethylhexanoate). J. Chem. Eng. Data 2005, 50, 939-946.

(44) Fandiño, O.; Garcia, J.; Comuñas, M. P. J.; López, E. R.; Fernández, J. $P \rho T$ Measurements and Equation of State (EoS) Predictions of Ester Lubricants up to $45 \mathrm{MPa}$. Ind. Eng. Chem. Res. 2006, 45, 1172-1182.

(45) Rodriguez, H.; Brennecke, J. F. Temperature and Composition Dependence of the Density and Viscosity of Binary Mixtures of Water + Ionic Liquid. J. Chem. Eng. Data 2006, 51, 2145-2155.

(46) Tokuda, H.; Tsuzuki, S.; Susan, M. A. B. H.; Hayamizu, K.; Watanabe, M. How Ionic Are Room-Temperature Ionic Liquids? An Indicator of the Physicochemical Properties. J. Phys. Chem. B 2006, 110, 1959319600.

(47) Arce, A.; Rodriguez, H.; Soto, A. Effect of anion fluorination in 1-ethyl-3-methylimidazolium as solvent for the liquid extraction of ethanol from ethyl tert-butyl ether. Fluid Phase Equilib. 2006, 242, $164-168$

(48) Vercher, E.; Orchilles, A. V.; Miguel, P. J.; Martinez-Andreu, A. Volumetric and Ultrasonic Studies of 1-Ethyl-3-methylimidazolium Trifluoromethanesulfonate Ionic Liquid with Methanol, Ethanol, 1-Propanol, and Water at Several Temperatures. J. Chem. Eng. Data 2007, 52, 1468-1482.

(49) MacFarlane, D. R.; Meakin, P.; Sun, J.; Amini, N.; Forsyth, M. Pyrrolidinium Imides: A New Family of Molten Salts and Conductive Plastic Crystal Phases. J. Phys. Chem. B 1999, 103, 4164-4170.

(50) Anthony, J. L.; Anderson, J. L.; Maginn, E. J.; Brennecke, J. F. Anion Effects on Gas Solubility in Ionic Liquids. J. Phys. Chem. B 2005, 109, 6366-6374.

(51) NIST Chemistry WebBook at http://webbook.nist.gov/chemistry/.

(52) Ionic Liquids in the Dortmund Data Bank, http://www.ddbst.de/new/ frame_ionic_liquids.htm.

(53) Ye, C.; Shreeve, J. M. Rapid and Accurate Estimation of Densities of Room-Temperature Ionic Liquids and Salts. J. Phys. Chem. A 2007, $111,1456-1461$

(54) Jenkins, H. D. B.; Roobottom, H. K.; Passmore, J.; Glasser, L. Relationships among Ionic Lattice Energies, Molecular (Formula Unit) Volumes, and Thermochemical Radii. Inorg. Chem. 1999, 38, 36093620 .

Received for review November 14, 2007. Accepted January 9, 2008. This work was supported by Fundação para a Ciência e a Tecnologia (Project POCI/EQU/58152/2004). R. L. Gardas and M. G. Freire acknowledge the financial support from Fundação para a Ciência e a Tecnologia through, respectively, their postdoctoral (SFRH/BPD/23246/2005) and $\mathrm{PhD}$. (SFRH/BD/14134/2003) scholarships.

JE700670K 